\title{
Formulation and evaluation of xanthan gum based aceclofenac tablets for colon targeted drug delivery
}

\author{
Thiruganesh Ramasamy ${ }^{1,4}$, Uma Devi Subbaih Kandhasami²,3,*, Himabindhu Ruttala ${ }^{4}$, \\ Suresh Shanmugam²
}

\begin{abstract}
${ }^{1}$ Research Associate, Department of Bioengineering and Regenerative medicine, Utah-Inha DDS \& Advanced Therapeutics Research Center, South Korea, ${ }^{2}$ Department of Pharmaceutics, School of Pharmaceutical Sciences, Vel's University, Chennai, India, ${ }^{3}$ Department of Pharmaceutics, Rao's College of Pharmacy, Nellore, India, ${ }^{4}$ Department of Pharmaceutics, Pydah College of Pharmacy, Kakinada, India
\end{abstract}

\begin{abstract}
The objective of the present study is to develop a colon targeted drug delivery systems for Aceclofenac using xanthan gum as a carrier. In this study, multilayer coated system that is resistant to gastric and small intestinal conditions but can be easily degraded by colonic bacterial enzymes was designed to achieve effective colon delivery of Aceclofenac. The xanthan gum, the drug and the physical mixture were characterized by Fourier transform infrared spectroscopy (FTIR) and differential scanning calorimetry (DSC). All the formulations were evaluated for hardness, drug content uniformity and other physical properties. Release aspects of Aceclofenac in simulated gastrointestinal fluid and colonic fluid with enzymes were investigated. From these results, Eudragit coated system exhibited gastric and small intestinal resistance to the release of Aceclofenac. The rapid increase in release of Aceclofenac in SCF was revealed as due to the degradation of the xanthan gum membrane by bacterial enzymes. The designed system could be used potentially as a carrier for colon delivery of Aceclofenac by regulating drug release in stomach and the small intestine.
\end{abstract}

Uniterms: Drugs/release colon targeted. Aceclofenac/release colon targeted. Xanthan gum. Colon targeting. Eudragit coating. In vitro dissolution. Targeted delivery.

O presente estudo teve como objetivo o desenvolvimento de sistema de liberação cólon-alvo de aceclofenaco empregando goma xantana. Nesse trabalho, o revestimento de múltiplas camadas com característica de resistência às condições do intestino delgado além de gastrorresistência oferece como vantagem a rápida degradação desse sistema por enzimas bacterianas colônicas. Dessa forma, o planejamento de tal sistema possibilitou a liberação específica do aceclofenaco no cólon. A goma xantana e o fármaco, além da mistura física desses dois componentes, foram caracterizados por espectroscopia no infravermelho com transformada de Fourier (FTIR) e calorimetria diferencial exploratória (DSC). Todas as formulações foram avaliadas no que se refere à dureza, à uniformidade de conteúdo do fármaco além de outras propriedades físicas. Os perfis de liberação do aceclofenaco no fluido gástrico simulado e fluido colônico simulado contendo enzimas foram investigados. Os resultados revelaram que o sistema revestido com Eudragit ${ }^{\circledR}$ exibiu resistência gástrica e intestinal à liberação de aceclofenaco. $\mathrm{O}$ rápido aumento na liberação de aceclofenaco no fluido colônico simulado foi atribuido à degradação da goma xantana por enzimas bacterianas. O sistema apresenta aplicação potencial no desenvolvimento de produtos para a liberação cólon-alvo de aceclofenaco.

Unitermos: Fármacos/liberação cólon-alvo Aceclofenaco/perfil de liberação. Goma xantana. Direcionamento ao cólon. Cobertura de Eudragit. Dissolução in vitro. Liberação dirigida.

*Correspondence: S. K. Uma Devi. Department of Pharmaceutics, School of pharmaceutical sciences, Vel's University, Chennai, Tamil Nadu, India- 600117. E-mail: umadeviphd@gmail.com 


\section{INTRODUCTION}

The oral route is considered to be most convenient for administration of drugs to patients. Oral administration of conventional dosage forms normally dissolves in the stomach fluid or intestinal fluid and absorb from these regions of the gastrointestinal tract (GIT) (Paharia et al., 2007). Dosage forms that deliver drugs into the colon rather than upper GIT offers number of advantages (Sarasija, Hota, 2000; Vaidya et al, 2009).

Many attempts have been made to achieve colon targeting that is advantageous in the treatment of colonic disease and as well as in the treatment of rheumatoid arthritis. A novel oral colon-specific drug delivery system (CDDS) has been developed as one of the site-specific drug delivery systems (Dhawale et al., 2010). This delivery system, by means of combination of one or more controlled release mechanisms, hardly releases drug in the upper part of the gastrointestinal (GIT) tract, but rapidly releases drug in the colon following oral administration. CDDS is convenient for treating localized colonic diseases, i.e. ulcerative colitis, Crohn's disease and constipation etc., CDDS, also selectively deliver drug to the colon, but not to the upper GI tract (Kinget et al., 1998; Watts, Illum 1997; Yang et al., 2002; Ravikumar et al., 2009). CDDS would be advantageous when a delay in absorption is desirable from a therapeutically point of view, as for the treatment of diseases that have peak symptoms in the early morning and that exhibit circadian rhythms, such as nocturnal asthma, angina and rheumatoid arthritis (Halsas et al., 1999b, 2001a).

Natural polysaccharides such as xanthan gum, xylan and guar gum are not digested in the human stomach or small intestine, but are degraded in the colon by resident bacteria (Salyers et al., 1977). A suspension of natural polygalactomannans in polymethacrylate solution applied as a degradable coating around the drug core delayed the drug release in the small intestine, but was degraded by colonic bacterial enzymes thereby releasing the drug (Lehmann, Dreher, 1991). Xanthan gum is a high molecular weight extracellular polysaccharide. The molecule consists of a backbone identical to that of cellulose, with side chains attached to alternate glucose residues. It is a hydrophilic polymer, which until recently had been limited for use in thickening, suspending and emulsifying water based systems (Dhopeshwarkar et al., 1994; Yeole et al., 2006). It appears to be gaining appreciation for fabrication of matrices, as it not only retards drug release, but also provides time- independent release kinetics with added advantages of biocompatibility and inertness. Release of soluble drugs was mainly through diffusion, whereas spa- ringly soluble or insoluble drugs were released via erosion. Xanthan gum has been evaluated as a hydrophilic matrix for controlled release preparations, using different model drugs including theophylline (Parfitt, 1999; Raja Sekharan et al., 2009), cephalexin (Kay, Alldred, 2003).

Non-steroidal anti-inflammatory drugs (NSAIDs) are considered to be the first-line drugs in the symptomatic treatment of rheumatoid arthritis (Moskowitz, 2001), osteoarthritis (Nisha et al., 2000) and ankylosing spondilytis (Medical online). Sustained release dosage forms deliver the drug at a slow rate over an extended period of time and achieve this object. Aceclofenac, (2-[2-[2-(2,6-dichlorophenyl) amino phenyl] acetyl] oxy acetic acid, a non steroidal anti-inflammatory drug (NSAID) is one of the emerging NSAID molecules for arthritis treatment (Rheumatoid arthritis guide; Drug details). Short biological half life (about 4 hour) and dosing frequency more than one per day make Aceclofenac an ideal candidate for sustained release. It is a newer derivative of diclofenac and has less gastrointestinal complications. The successful treatment of arthritis depends on the maintenance of effective drug concentration level in the body for which a constant and uniform supply of drug is desired (Munira Momin, Pundarikakshudu, 2004; Liu, et al., 2003). In this study, multilayer coated system that is resistant to gastric and small intestinal conditions but can be easily degraded by colonic bacterial enzymes was designed to achieve effective colon delivery of aceclofenac.

\section{MATERIALS AND METHODS}

\section{Materials}

Materials used included Aceclofenac, which was kindly provided as a gift sample by Restek Pharma, Pondicherry. Xanthan gum was purchased from Indian Research Products, Chennai. Eudragit S 100 and Eudragit L 100 were purchased from Loba chemicals, Mumbai. All other chemicals were of analytical grade.

\section{Preparation of Xanthan gum tablets}

\section{Step-I}

Aceclofenac tablets, each containing $100 \mathrm{mg}$ of aceclofenac and weighing 232 to $262 \mathrm{mg}$ were prepared by wet granulation and direct compression techniques using xanthan gum as a polymer. Formulations (F1-F4) were blended and granulated with starch mucilage. The wet mass was passed through a mesh $(1000 \mu \mathrm{m})$ sieve and the granules were dried at $50^{\circ} \mathrm{C}$ for $2-3 \mathrm{~h}$. The dried granules were sieved $(650 \mu \mathrm{m})$, lubricated with magnesium stearate 
TABLE I - Composition of aceclofenac tablet

\begin{tabular}{lcccc}
\hline \multirow{2}{*}{ Ingredients (mg) } & \multicolumn{4}{c}{ Quantity $(\mathrm{mg})$ present in each tablet } \\
\cline { 2 - 5 } & $\mathrm{AXT}_{1}$ & $\mathrm{AXT}_{2}$ & $\mathrm{AXT}_{3}$ & $\mathrm{AXT}_{4}$ \\
\hline Aceclofenac & 100 & 100 & 100 & 100 \\
Xanthan gum & 10 & 20 & 30 & 40 \\
Microcrystalline cellulose & 90 & 90 & 90 & 90 \\
Mucilage of starch 7.5\% & 20 & 20 & 20 & 20 \\
Magnesium stearate 3\% & 7 & 7 & 7 & 7 \\
Talc (2\%) & 5 & 5 & 5 & 5 \\
Total & 232 & 242 & 252 & 262 \\
\hline
\end{tabular}

and talc mixture and compressed on a single-punch tablet machine, using $12 \mathrm{~mm}$ round slightly concave punches (Gang Cheng et al., 2004; Lachman et al., 2004). The preparation of xanthan gum tablets were given in Table I.

\section{Step - II}

The optimized batches of xanthan gum tablets were given a coating of Eudragit L-100 and S-100 mixture in a fluidized bed coating apparatus. In-process samples at various coating levels $5,10 \% \mathrm{w} / \mathrm{w}(\%$ polymeric weight gain) were taken to check the morphology of coating to do dissolution studies in simulated fluids of stomach and small intestine. After the coating, the tablets were gently fluidized for about 5 min after which they were air dried in an oven for $24 \mathrm{~h}$ at $40{ }^{\circ} \mathrm{C}$. A $10 \% \mathrm{w} / \mathrm{w}$ increase in the coating level was selected as an optimum coating percentage level for all the tablets. Then the $\mathrm{pH}$ dependent polymeric coated tablets were tested for drug release studies in the simulated gastric fluid (SGF), simulated intestinal fluid (SIF) and simulated colonic fluid (SCF) separately (Train 1958).

\section{Preformulation studies}

\section{Differential scanning calorimetry}

The DSC curves of Aceclofenac, xanthan gum and mixture of Aceclofenac/xanthan gum (10:4) were generated by a differential scanning calorimeter (DSC $220 \mathrm{C}$, SEIKO, Japan) at heating rate of $10^{\circ} \mathrm{C} / \mathrm{min}$ from 60 to $200{ }^{\circ} \mathrm{C}$. Accurately $12 \mathrm{mg}$ of sample was taken in a standard pan and placed at sample stage. Nitrogen flow was set at $50 \mathrm{~cm}^{3} / \mathrm{min}$ and the nitrogen flow rate to the chamber was $80 \mathrm{~cm}^{3} / \mathrm{min}$.

\section{Fourier transforms Infrared spectroscopy}

FT-IR spectra of Aceclofenac, xanthan gum and mixture of Aceclofenac/xanthan gum were recorded at room temperature in $\mathrm{KBr}$ pellets by applying $6000 \mathrm{~kg} / \mathrm{cm}^{2}$ pressure by using a Shimadzu FT-IR 8300 Spectrophotometer (Shimadzu,Tokyo,Japan) in the wavelength region between 400 to $4000 \mathrm{~cm}^{-1}$.

\section{Standard plot of aceclofenac in $\mathrm{pH} 7.0$ phosphate buffer saline}

$100 \mathrm{mg}$ of aceclofenac (standard drug) was accurately weighed and dissolved using $\mathrm{pH} 7.0$ phosphate buffer saline (PBS) solution in $100 \mathrm{ml}$ standard flask and 5, 10, 15,20 and $25 \mu \mathrm{g} / \mathrm{mL}$ were prepared by suitably diluting the stock solutions with $\mathrm{pH}$ 7.0 PBS, each sample was then analysed spectrophotometrically at $275 \mathrm{~nm}$ using ELICO SL -159 double beam UV Visible spectrophotometer.

\section{Evaluation of granules}

The granules were evaluated for their flow properties, the Carr index (compressibility index) and Hausner ratio. The flow rate $(\mathrm{g} / \mathrm{s})$ was calculated from the time needed for the entire sample ( $40 \mathrm{~g}$ ) to empty from the funnel. Bulk density was calculated from the amount of granules poured into a $100 \mathrm{~mL}$ graduated cylinder up to a total volume of $50 \mathrm{~mL}$ while for the tap density determination; the cylinder was tapped until no measurable change in the volume was observed. The bulk density (BD) and tapped density (TD) were calculated from equation 1 and 2 .

Bulk density $=$ Weight of the powder/Bulk volume Eq. 1

Tapped density $=$ Weight of thr powder/Tapped volume Eq. 2

Based on bulk density and tap density, both the Carr Index (\%) and Hausner's ratio were calculated.

The Carr's index was calculated by the equation 3 :

Carr's index $(\%)=[(\mathrm{TD}-\mathrm{BD}) * 100] / \mathrm{TD} \quad$ Eq. 3

The Hausner's ratio was calculated by the equation 4: 
Hausner's Ratio $=\mathrm{TD} / \mathrm{BD}$

Eq. 4

Angle of repose was determined by fixed funnel method. Funnel with the end of the stem cut perpendicular to the axis of symmetry was secured with its tip at a given height $(\mathrm{H})$ above a graph paper placed on a flat horizontal surface. The material was carefully poured through the funnel until the apex of the conical pile so formed just touches the tip of the funnel. The mean diameter of the base of powder cone was determined and the tangent of the angle of repose was calculated by equation 5: (Carr, 1965; Hausner, 1967; US Pharmacopeia, 2004; Bi et al., 1996).

$\tan \alpha=H / R$

Eq. 5

where $\alpha$ is the angle of repose.

\section{Evaluation of tablets}

Prepared matrix tablets were evaluated for thickness by using digital micrometer (Mityato, Japan). Hardness of the tablet was determined by using a Monsanto hardness tester, which is expressed in $\mathrm{kg} / \mathrm{cm}^{2}$. Friability of the tablet was determined using Roche Friabilator, which is expressed in percentage. Twenty tablets were initially weighed (W initial) and transferred into the friabilator. The friabilator was operated at $25 \mathrm{rpm}$ per min for four minutes (per 100 revolutions). The tablets were weighed again $\left(\mathrm{W}_{\text {final }}\right)$ and the percentage of friability was then calculated by using the following formula, $\left(\mathrm{F}=\mathrm{W}_{\text {initial }}-\mathrm{W}_{\text {final }} / \mathrm{W}_{\text {initial }} \times 100\right)$. For Weight Variation, USP 2004 procedure for uniformity of weight was followed, twenty tablets were taken and their weight was determined individually and collectively on a digital weighing balance (Shimadzu, Japan). The average weight of one tablet was determined from the collective weight (Gohel et al., 2005; Chourasia, Jain, 2003; James Swarbrick, 2003).

\section{Drug content}

The drug content was determined by Absorbance of aliquots solutions and was measured in a spectrophotometer at $275 \mathrm{~nm}$. Simultaneously, a $10 \mu \mathrm{g} / \mathrm{mL}$ of aceclofenac standard solution prepared in the same medium was recorded and content of Aceclofenac was calculated (United States Pharmacopoeial Convention 1999; Sinha et al., 2004).

\section{In vitro drug release studies in simulated fluids}

The ability of xanthan gum tablets of Aceclofenac to remain intact in the physiological environment of stomach and small intestine was assessed by mimicking mouth to colon transit. Drug release studies were carried out using USP XXIII dissolution apparatus $\left(100 \mathrm{rpm}, 37 \pm 0.5^{\circ} \mathrm{C}\right)$ in $900 \mathrm{~mL}$ of simulated gastric fluid (SGF) $\mathrm{pH} 1.2$ (USP 2008) for $2 \mathrm{~h}$ as the average gastric emptying time is $\sim 2 \mathrm{~h}$. The dissolution medium was replaced with $900 \mathrm{~mL}$ of simulated intestinal medium (SIF) pH 7.4 (USP 2008) and the dissolution was continued for $24 \mathrm{~h} .1 \mathrm{~mL}$ of the sample was taken at the end of the specified time period and analyzed for Aceclofenac spectrophotometrically at $275 \mathrm{~nm}$. A $10 \mathrm{~mL}$ volume of filtered, fresh dissolution medium was added to make the volume after each sample withdrawal (Paharia et al., 2007). The susceptibility of the matrix tablets to the enzymatic action of colonic bacteria was assessed by continuing the drug release studies in simulated colonic fluids prepared using rat cecal content as described by Sinha et al. (2004).

\section{In vitro drug release study in the presence of rat cecal content}

Rat cecal content was prepared by taking four albino rats of uniform body weight (150-200 g) with no prior drug treatment. They were weighed, maintained on normal diet, and administered $1 \mathrm{~mL}$ of $2 \%$ dispersion of xanthan gum in water, and this treatment was continued for 7 days for polymer induction to animals. Thirty minutes before starting the study, each rat was humanely killed and the abdomen was opened. The cecal were traced, legated at both ends, dissected, and immediately transferred into phosphate buffered saline (PBS) $\mathrm{pH} 6.8$, which was previously bubbled with $\mathrm{CO}_{2}$. The cecal bag was opened; the contents were weighed, homogenized and then suspended in PBS ( $\mathrm{pH} 7.4)$ to give the desired concentration ( $2 \%$ ) of cecal content, which was used as simulated colonic fluid. The suspension was filtered through cotton wool and ultrasonicated for 10 minutes in an ice bath at $40 \%$ voltage frequency using a probe sonicator (Soniweld, Imeco U1trasonics, Mumbai, India) at $4{ }^{\circ} \mathrm{C}$ to disrupt the bacterial cells. After sonication, the mixture was centrifuged (Remi) at $2000 \mathrm{rpm}$ for 20 minutes.

Tablets were placed in $200 \mathrm{~mL}$ of dissolution media (PBS, pH 7.4) containing 2\% w/v rat cecal content. The experiment was performed with continuous $\mathrm{CO}_{2}$ supply into the dissolution medium. At different time intervals, the samples were withdrawn and replaced with fresh PBS. The experiment was continued up to 24 hours. The withdrawn samples were pipetted into a series of $10 \mathrm{~mL}$ volumetric flasks, and volumes were made up to the mark with PBS and centrifuged. The supernatant was filtered through $0.45-\mu \mathrm{m}$ membrane filter and the filtrate analyzed for Aceclofenac content at $275 \mathrm{~nm}$ using UV spectropho- 
tometer method. All the experiments were performed in triplicate (Avachat et al., 2007). The interference of rat caecal content on the aceclofenac determination was not significant (P-value $>0.001)$ and hence not taken into consideration.

\section{Quantification of the water uptake and erosion determination}

For conducting water uptake studies, the dissolution jars were marked with the time points of $0.5,1,2$, up to 9 hours. One tablet was placed in each dissolution jar containing $900 \mathrm{~mL}$ of phosphate buffer $\mathrm{pH} 7.4$ buffers at $37{ }^{\circ} \mathrm{C} \pm 0.5^{\circ} \mathrm{C}$, and the apparatus was run at $100 \mathrm{rpm}$ using paddle. The tablets were taken out after completion of the respective stipulated time span as mentioned above and weighed, after the excess of water at the surface had been removed with filter paper. The wetted samples were then dried in an oven at $40{ }^{\circ} \mathrm{C}$ up to constant weight. The increase of the weight on the tablet reflects the weight of the liquid uptake. It was estimated according to Equation 6.

$\mathrm{Q}=100(\mathrm{Ww}-\mathrm{Wi}) / \mathrm{Ww}$

Eq. 6

Where $\mathrm{Q}$ is the percentage of the liquid uptake, and $\mathrm{Ww}$ and $\mathrm{Wi}$ are the masses of the hydrated samples before drying and the initial starting dry weight, respectively.

The degree of erosion (expressed as percentage erosion of the polymer content, E) was determined using Equation 7.

$E=100\left(W_{i}-W_{f}\right) W_{i}$

Where $\mathrm{W}_{\mathrm{f}}$ is the final mass of the same dried and partially eroded sample.

The entire process was repeated to get 3 values for each time point, and the average was calculated.

\section{In vitro release kinetics}

In order to investigate the mode of release from tablets, the release data of F1 was analyzed with the following mathematical models: $\mathrm{Q}=\mathrm{K}_{\mathrm{o}} \mathrm{t}$ (Zero order kinetic), $\ln (100-\mathrm{Q})=\ln _{\mathrm{o}}-\mathrm{K}_{1} \mathrm{t}$ (First order kinetic) and $\mathrm{Q}=\mathrm{Kptn}$ (Korsemeyer and Peppas equation), where, $\mathrm{Q}$ is the percent of drug released at time $t$ and $\mathrm{Ko}$ and $\mathrm{K}_{1}$ are the coefficients of the equations. $\mathrm{Kp}$ is constant incorporating structural and geometric characteristics of the release device, and $\mathrm{n}$ is the release exponent indicative of mechanism of release (Hadi, Seyed 2005).

\section{Statistical analysis}

The cumulative percent release of aceclofenac from tablets in different medium was compared and the statistical significance was tested using student's t-test. A P-value $<0.05$ was considered statistically significant.

\section{RESULTS AND DISCUSSION}

\section{DSC studies}

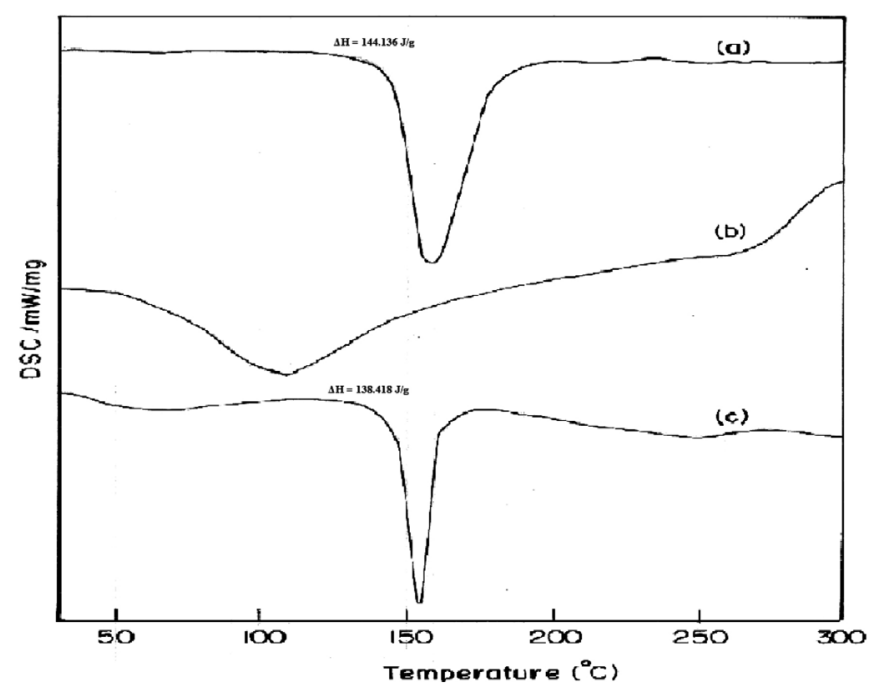

FIGURE 1 - DSC graphs of (a) Aceclofenac, (b) Xanthan gum, (c) Physical mixture of aceclofenac and xanthan gum.

DSC provides useful information about the physical properties of the sample as crystalline or amorphous nature and demonstrates a possible interaction between drug and polymers in formulations. The thermal curves of pure Aceclofenac, xanthan gum and Aceclofenac/xanthan gum mixture were reported in Figure 1. The thermal curve of Aceclofenac exhibited a profile typical of a pure, crystalline, anhydrous drug, with a sharp endothermic peak $\left(\mathrm{T}\right.$ peak $\left.=158.3^{\circ} \mathrm{C}\right)$ due to its melting process. The thermal profile of xanthan gum revealed a melting phenonmenon at around $90-120^{\circ} \mathrm{C}$, that is endothermic peak observed for xanthan gum at $108.9^{\circ} \mathrm{C}$. While the drug melting peak is still well visible in physical mixture (Aceclofenac/xanthan gum) thermogram at $160{ }^{\circ} \mathrm{C}$, Thus the thermograms of physical mixture showed that no interactions between Aceclofenac and xanthan gum. With regard to crystallinity, there was no noticeable reduction in heat of fusion $(\Delta \mathrm{H})$, in physical mixtures $(138.418 \mathrm{~J} / \mathrm{g})$ as compared to pure Aceclofenac $(144.316 \mathrm{~J} / \mathrm{g})$. These suggest that the physical mixture could able to maintain the crystalline form of Aceclofenac. However it has been known that 
transforming the physical state of the drug to amorphous or partially amorphous state leads to a high energy state and high disorder, resulting in enhanced solubility and faster dissolution.

\section{IR STUDIES}

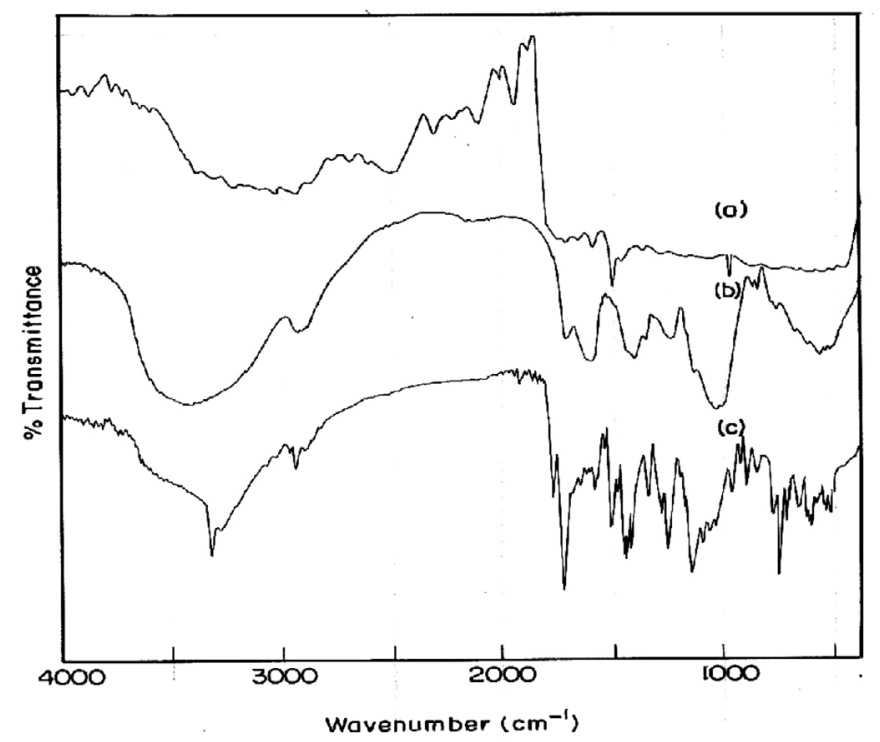

FIGURE 2 - FT-IR graphs of (a) Aceclofenac, (b) Xanthan gum, (c) Physical mixture of aceclofenac and xanthan gum.

FT-IR spectral data were used to ensure no chemical interaction and to confirm the chemical stability of Aceclofenac in the physical mixture. The FTIR of Aceclofenac showed intense band at $1771.47 \mathrm{~cm}^{-1}, 1716.89 \mathrm{~cm}^{-1}$, $1589.53 \mathrm{~cm}^{-1}$ and $1055.9 \mathrm{~cm}^{-1}$ corresponding to the functional groups $\mathrm{C}=\mathrm{O}, \mathrm{COOH}, \mathrm{NH}$ and $\mathrm{OH}$ bending. The peaks observed in FTIR of physical mixture of aceclofenac and xanthan gum was almost unchanged and was found to be at $1771.56 \mathrm{~cm}^{-1}, 1716.94 \mathrm{~cm}^{-1}, 1586.5 \mathrm{~cm}^{-1}, 1054.5 \mathrm{~cm}^{-1}$ respectively. Hence, all the peaks observed in plain aceclofenac were also observed in the physical mixture too, indicating no interaction of aceclofenac with the polymer. The IR graphs were given in Figure 2.

\section{Micromeritic properties}

The micromeritic properties of all the formulations were compared and presented in Table II.

The Hausner ratio is used widely in pharmaceutical industry as an indication of the flowability of a powder. A Hausner ratio less than 1.25 is considered to be an indication of good flowability and anything below 1.20 is regarded as excellent flow. The Hausner's ratio varied from 1.19 to 1.25 for AXT 1 to AXT4 indicating its excellent flowability. The Carr's index is also used in pharmaceutics as an indication of the flowability of a powder and the values ranging from $15-25$ is regarded as the good value for flowability perhaps our observation of the result was good for all the formulations. Similarly angle of repose of all the formulations were also good, showing good flowability.

However from all the observations, we learned that, $\mathrm{AXT}_{1}$ batch was optimal due to good Hausner's ratio(1.19), good carr's index(16.66) and good angle of repose $\left(16^{\circ} 16^{\prime}\right)$, which indicates the batch $\mathrm{AXT}_{1}$ granules have good flow property and easily compressed into tablets. The results of micromeritic properties of AXT were given in Table II.

\section{Physical properties}

The hardness of tablet increased with the increase

TABLE II - Physical and micromeritic properties of aceclofenac and xanthan gum granules

\begin{tabular}{lcccc}
\hline Test & $\mathrm{AXT}_{1}$ & $\mathrm{AXT}_{2}$ & $\mathrm{AXT}_{3}$ & $\mathrm{AXT}_{4}$ \\
\hline Bulk density & $0.507 \pm 0.92$ & $0.557 \pm 1.12$ & $0.612 \pm 0.18$ & $0.672 \pm 0.15$ \\
Tapped density & $0.603 \pm 1.23$ & $0.668 \pm 0.08$ & $0.746 \pm 1.94$ & $0.833 \pm 1.17$ \\
Carr's index & $18.93 \pm 1.18$ & $19.92 \pm 0.54$ & $21.89 \pm 1.08$ & $23.95 \pm 1.76$ \\
Hausner's ratio & $1.19 \pm 1.67$ & $1.22 \pm 0.65$ & $1.23 \pm 0.87$ & $1.25 \pm 0.67$ \\
Angle of repose & $16^{\circ} 16^{\prime} \pm 0.35$ & $16^{\circ} 78^{\prime} \pm 0.56$ & $17^{\circ} 78^{\prime} \pm 1.42$ & $19^{\circ} 21^{\prime} \pm 1.42$ \\
Weight (mg) & $232 \pm 1.02$ & $242 \pm 1.05$ & $252 \pm 0.12$ & $263 \pm 0.26$ \\
Drug content (\%) & $99.20 \pm 0.20$ & $101.2 \pm 0.86$ & $99.53 \pm 0.12$ & $99.16 \pm 0.26$ \\
Hardness kg/cm ${ }^{2}$ & $5.3 \pm 1.0$ & $5.5 \pm 0.15$ & $5.6 \pm 0.80$ & $6.2 \pm 1.12$ \\
Thickness (mm) & $3.01 \pm 0.66$ & $3.2 \pm 1.04$ & $3.5 \pm 1.08$ & $3.9 \pm 0.12$ \\
Friability (\%) & $0.17 \pm 0.84$ & $0.20 \pm 0.62$ & $0.34 \pm 0.56$ & $0.32 \pm 0.48$ \\
\hline
\end{tabular}

$\mathrm{n}=3$, the values are mean \pm S.D 
in the polymer concentrations as evident from the following data i.e. the hardness was $5.3 \mathrm{~kg} / \mathrm{cm}^{2}\left(\mathrm{AXT}_{1}\right)$ and it increased to $6.2 \mathrm{~kg} / \mathrm{cm}^{2}\left(\mathrm{AXT}_{4}\right)$ for the rise in polymer concentration. Similarly the thickness also increased with the raised polymer concentrations. It varied from $3.01 \mathrm{~mm}$ to $4.0 \mathrm{~mm}$ for $\mathrm{AXT}_{1}-\mathrm{AXT}_{4}$ batches. The total drug content also varies between $99-101 \%$ for all the formulations and was lying within the pharmacopoeial limits. The results of physical properties of AXT were given in Table II.

\section{Percentage swelling and erosion}

The quantity of water uptake increased from $15.12 \pm 0.83$ to $43.15 \pm 0.45 \% \mathrm{w} / \mathrm{v}$ for $\mathrm{AXT}_{1}$ to $\mathrm{AXT}_{4}$ tablets respectively. The water uptake for each batch of tablets had increased upto $3^{\text {rd }}$ hour and then started to decrease. This indicates that the xanthan gum tablets require minimum 3 hours for reaching the maximum swelling. The results of swelling ratio were given in Figure 3. Where as the percent erosion decreased with the increase in the polymer concentration as the percent erosion was $25.1 \pm 0.22 \% \mathrm{w} / \mathrm{v}$

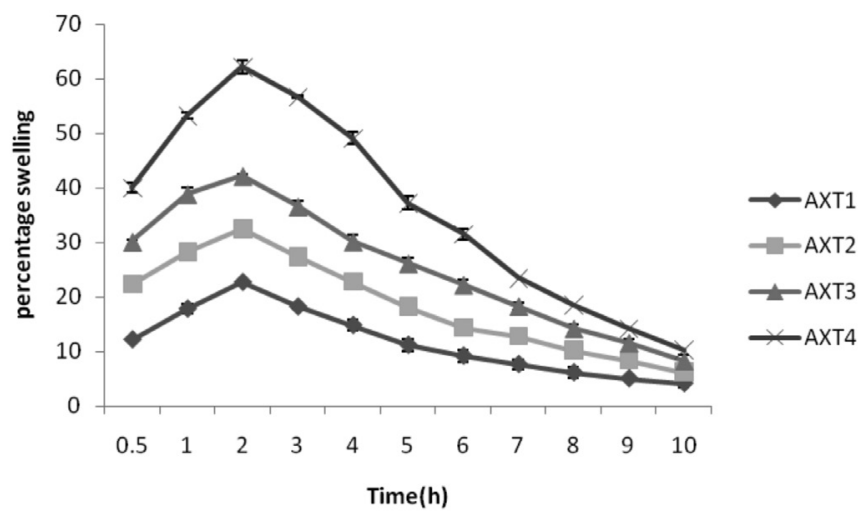

FIGURE 3 - Percentage swelling of aceclofenac-xanthan gum tablets (AXM 1 to AXM 4).

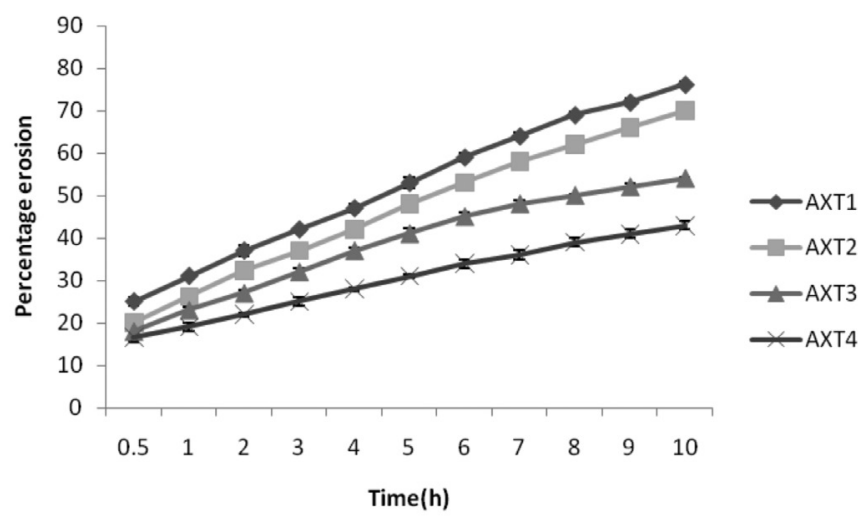

FIGURE 4 - Percentage erosion of aceclofenac-xanthan gum tablets (AXM 1 to AXM 4). for $\mathrm{AXT}_{1}$ and $16.5 \pm 0.15 \% \mathrm{w} / \mathrm{v}$ for $\mathrm{AXT}_{4}$ at $30 \mathrm{~min}$. While erosion increases with the increase in the time period so that erosion percentage was $76.2 \pm 0.28 \% \mathrm{w} / \mathrm{v}$ for $\mathrm{AXT}_{1}$ batch and $42.2 \pm 0.08 \% \mathrm{w} / \mathrm{v}$ for $\mathrm{AXT}_{4}$ batch at $10^{\text {th }}$ hour. The results of percentage erosion are given in Figure 4.

\section{In vitro drug release studies}

The matrix tablets were subjected to in vitro drug release study in SGF, SIF and SCF.

\section{In simulated gastric fluid (SGF)}

The percent drug release decreased with the increase in the xanthan gum concentration and virtually there is no release at the $30^{\text {th }} \mathrm{min}$. At the $120^{\text {th }} \mathrm{min}$ the release was $8.1 \pm 0.26 \% \mathrm{w} / \mathrm{v}$ for $\mathrm{AXT}_{1}$ and it decreased towards the final formulation as it was found to be $1.15 \pm 0.08 \% \mathrm{w} / \mathrm{v}$ for $\mathrm{AXT}_{4}$. This is due to the time lag for swelling of the tablets. It requires at least $30 \mathrm{~min}$ for swelling and then it started releasing the drug, in a very controlled manner. All formulation showed very low drug release in $\mathrm{pH} 1.2$ buffer. This may be due to the less solubility of Aceclofenac in $\mathrm{pH}$ 1.2.

\section{In simulated intestinal medium (SIF) and in simulated colonic fluid (SCF)}

The cumulative drug release decreased in $\mathrm{pH} 7.4$ buffer also with the increase in the polymer concentration as evident from the Figure 5. In SIF, AXT 1 batch showed a release of $4.64 \pm 0.06 \% \mathrm{w} / \mathrm{v}$ and it reduced to $3.12 \pm 0.08 \%$ $\mathrm{w} / \mathrm{v}$ for $\mathrm{AXT}_{2}$ while there is a no release for the next two formulations at $30 \mathrm{mins}$. The same trend persisted at $6^{\text {th }}$ hour i.e. drug release was $43.17 \pm 0.04 \% \mathrm{w} / \mathrm{v}$ for $\mathrm{AXT}_{1}$ and it decreased towards $\mathrm{AXT}_{4}$ with a drug release of $15.13 \pm 0.12 \%$. However the release percentage for $\mathrm{AXT}_{1}$

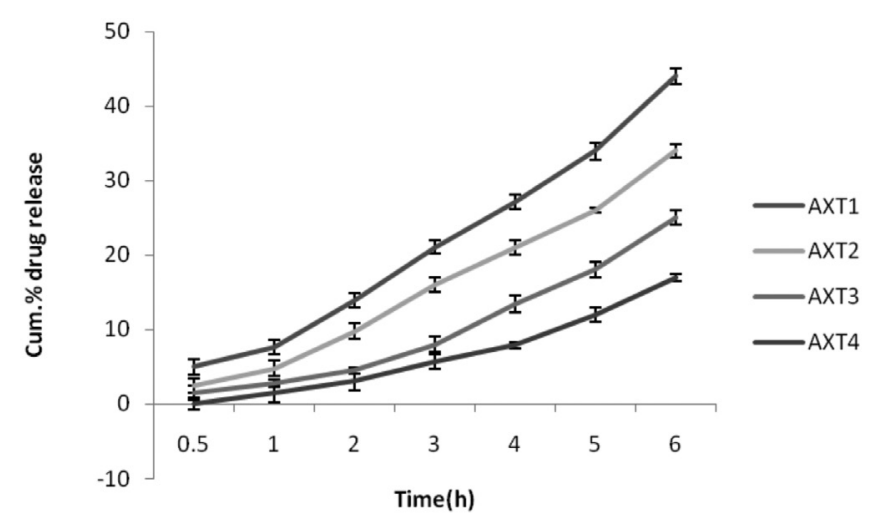

FIGURE 5 - Cumulative percentage drug release of fromulations (AXT 1 to AXT 4) in SIF. 
was up to $101.14 \pm 0.89 \% \mathrm{w} / \mathrm{v}$ at the end of $12^{\text {th }}$ hour in the dissolution medium containing $\mathrm{pH} 7.4$ buffer with rat caecal contents $(4 \% \mathrm{w} / \mathrm{v})$ and it decreased towards the final formulation. From this it was proved that $\mathrm{AXT}_{3}$ and $\mathrm{AXT}_{4}$ batch were not releasing much amount of drug in the stomach and intestinal medium.

From the dissolution studies conducted for $\mathrm{AXT}_{1}$, $\mathrm{AXT}_{2}, \mathrm{AXT}_{3} \& \mathrm{AXT}_{4}$ in simulated intestinal medium it has been understood that $\mathrm{AXT}_{1} \& \mathrm{AXT}_{2}$ tablets which were containing gum in 1:10 and 2:10 ratio are not protecting the drugs release in the gastric media. Upto $38.17 \pm 0.04 \% \mathrm{w} / \mathrm{v}$ and $34.12 \pm 0.12 \% \mathrm{w} / \mathrm{v}$ of drug have been released from the $\mathrm{AXT}_{1}$ and $\mathrm{AXT}_{2}$ batches at the end of the studies where as $\mathrm{AXT}_{3} \& \mathrm{AXT}_{4}$ batch significantly (p-value $<0.05$ ) released lesser amount of drug at the end of $6^{\text {th }}$ hour.

Since the batches $\mathrm{AXT}_{1} \& \mathrm{AXT}_{2}$ were released $80.15 \pm 1.04 \% \mathrm{w} / \mathrm{v} \& 70.19 \pm 0.14 \% \mathrm{w} / \mathrm{v}$ of the drug in the colonic fluid at $8^{\text {th }}$ and $10^{\text {th }}$ hour, they were considered as suitable batches for colon targeting. To prevent the drug release from $\mathrm{AXT}_{1} \& \mathrm{AXT}_{2}$ batches in the stomach \& intestinal media, a suitable enteric coating can be given. So that the drug release will be completely prevented in the SGF.

The present study was aimed to develop a targeted drug delivery system of Aceclofenac to treat the symptoms of rheumatoid arthritis. By observing the above results it was found that, though $\mathrm{AXT}_{1}$ and $\mathrm{AXT}_{2}$ batches released $10.28 \pm 0.83 \% \mathrm{w} / \mathrm{v}$ and $8.16 \pm 0.48 \% \mathrm{w} / \mathrm{v}$ of the drug in simulated gastric fluid and $38.17 \pm 0.04 \% \mathrm{w} / \mathrm{v}$ and 34.12 $\pm 0.12 \% \mathrm{w} / \mathrm{v}$ in the simulated intestinal fluid. They release upto $101.14 \pm 0.89 \% \mathrm{w} / \mathrm{v} \& 89.11 \pm 0.17 \% \mathrm{w} / \mathrm{v}$ at end of the $12^{\text {th }}$ hour in the simulated colonic medium. If they were given an enteric coating, the drug release in the stomach and intestine can be completely prevented. The $\mathrm{AXT}_{3}$ and $\mathrm{AXT}_{4}$ batches, though they prevent drug release in the simulated stomach and intestinal fluid to a considerable extent, they are not showing good release in the simulated colonic medium. So they were not considered as suitable formulations.

So the $\mathrm{AXT}_{1}$ batch, which released a maximum percent of drug i.e. $80.12 \% \mathrm{w} / \mathrm{v}$ at the $8^{\text {th }}$ hour in colonic medium was selected to give Eudragit coating to prevent the drug release in acidic medium and to start release the drug at the ileocaecal junction at the threshold value of $\mathrm{pH}$ upon dissolution of Eudragit in 7 or above 7.0. The results for cumulative drug release of various formulations in SCF were given in Figure 6.

\section{Step II}

The optimized batch $\mathrm{AXT}_{1}$ was given a $\mathrm{pH}$ dependent polymeric coating to get a weight of $15 \% \mathrm{w} / \mathrm{w}$ to the tablet weight. The percentage weight gain was checked

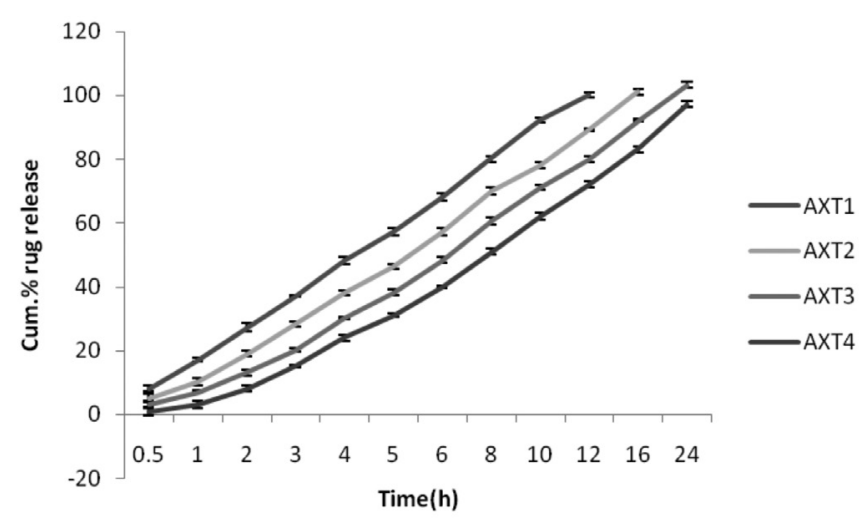

FIGURE 6 - Cumulative percentage drug release of fromulations (AXT 1 to AXT 4) in SCF.

during the coating process to find the coating level necessary to retard the drug release in simulated gastric fluid for 2 hours. The coated tablets were subjected for dissolution studies in SIF and SCF.

\section{In SGF}

Upto $120 \mathrm{~min}$, there was no drug release obtained in the simulated stomach fluid which reveals that a $15 \%$ $\mathrm{w} / \mathrm{w}$ increase in coating level is enough to prevent the drug release in SGF upto $120 \mathrm{~min}$.

\section{In SIF and SCF}

The percentage release was $4.88 \pm 0.86$ in SIF at the end of 6th hour and $103.12 \pm 0.6 \%$ in SCF at the end of $24^{\text {th }}$ hour. These results revealed that concentration of $4.3 \% \mathrm{w} / \mathrm{w}$ of xanthan gum to tablet weight was the optimized one as it released $80.64 \pm 0.65 \% \mathrm{w} / \mathrm{v}$ in SCF at the end of $8^{\text {th }}$ hour. The results for percentage drug release of $\mathbf{E}-\mathrm{AXT}_{1}$ tablets in SIF and SCF are given in Figure 7.

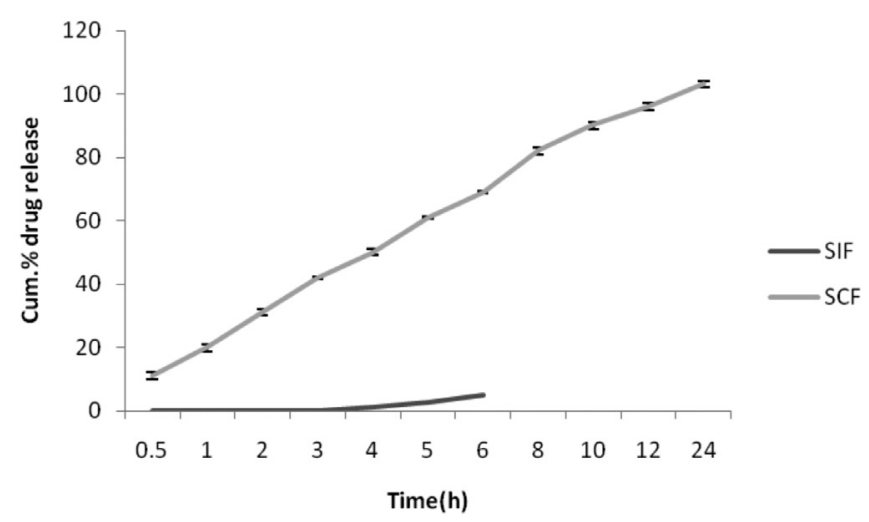

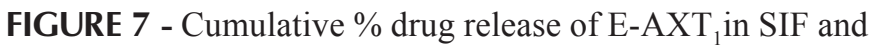
SCF. 
TABLE III - In vitro release kinetics of $\mathrm{AXT}_{1}-\mathrm{AXT}_{4}$ tablets

\begin{tabular}{|c|c|c|c|c|c|}
\hline \multirow[t]{2}{*}{ Formulation } & \multirow{2}{*}{$\begin{array}{c}\text { Zero order } \\
\mathrm{R}^{2}\end{array}$} & \multirow{2}{*}{$\begin{array}{c}\text { First order } \\
\mathrm{R}^{2}\end{array}$} & \multirow{2}{*}{$\begin{array}{l}\text { Higuchi } \\
\mathrm{R}^{2}\end{array}$} & \multicolumn{2}{|c|}{ Korsemeyer-Peppas } \\
\hline & & & & $\mathrm{R}^{2}$ & 'n' \\
\hline AXT1 & 0.9978 & 0.566 & 0.9985 & 0.998 & 0.81 \\
\hline AXT2 & 0.9888 & 0.716 & 0.9845 & 0.991 & 0.74 \\
\hline AXT3 & 0.9865 & 0.701 & 0.9802 & 0.982 & 0.70 \\
\hline AXT4 & 0.9848 & 0.668 & 0.9824 & 0.979 & 0.73 \\
\hline
\end{tabular}

$\mathrm{R}^{2}$ : Coefficient of determination

\section{In vitro release kinetics}

When the data were plotted according to the first order equation, all the formulation showed a fair linearity, with $\mathrm{R}^{2}$ value between $(0.566-0.716)$, when the same data was plotted according to the zero order equation, it shown a good linearity with $\mathrm{R}^{2}$ value between $(0.9848$ - 0.9978). The in vitro release kinetics of $\mathrm{AXT}_{1}$ is given in Table III.

\section{DISCUSSION}

The objective of the present study was to develop a controlled release colon targeted drug delivery system of Aceclofenac to approximate the chronobiology of rheumatoid arthritis. A combination of $\mathrm{pH}$ sensitive polymer coating and embedment in biodegradable matrices has been followed for preparation of formulations. The Eudragit coated matrices of polysaccharides are assumed to remain intact in the physiological environment of stomach and small intestine but once they reach the colon, they are acted upon by the bacterial polysaccharidase resulting in degradation and release of entrapped drug. Xanthan gum have been reported to possess ideal qualities for sustained release of the drug to the targeted site (Mundargi et al., 2007; Sinha et al., 2007).

The xanthan gum tablets were prepared by wet granulation method. All the formulations showed a good micromeritic property. The values for Carr's index $(\%)$ and Hausner's ratio, angle of repose $\left(^{\circ}\right)$ were within specified range indicating good flowability, which is inturn required for the good tableting. Plain Aceclofenac exhibited poor flowability as evident by the angle of repose value of $38.42 \pm 0.52$. It was further supported by high Carr's index value of $29.69 \pm 0.27$ and Hausner's ratio of $1.44 \pm 0.08$ (Mutalik et al., 2008). Where as all the prepared granules possessed good flow properties as indicated by low values of Angle of repose $\left(16^{\circ} 16^{\prime} \pm 0.35-19^{\circ} 21^{\prime} \pm 1.42\right)$, Carr's index (18.93 $\pm 1.18-23.95 \pm 1.76)$ and Hausner's ratio (1.19 $\pm 1.67-1.25 \pm 0.67)$. Among all the preparation, $\mathrm{AXT}_{1}$ was found to be good due its low Hausner's ratio, compressibility index and angle of repose values. The hardness of the tablets was increased with the increase in xanthan gum concentration. Thus various concentrations of polymers had influence on physical characteristics of the tablets.

Evaluation of polymer swelling and erosion is a valuable exercise to better understand the mechanisms of release and the relative importance of participating parameters. The tablets prepared with high concentrations of xanthan gum showed a lower rate of erosion and a faster rate of swelling, as compared with the tablets containing lower concentrations of xanthan gum. This effect may be attributed to an increase of water uptake in the presence of a larger amount of the polymer and viscoelastic mass formation (Talukdar et al., 1995). Perhaps the viscoelastic mass formation also attributed to interaction of xanthan gum with the starch mucilage due to intermolecular interaction (Ntawukulilyayo et al., 1996) 1, 2 After $4^{\text {th }} \mathrm{h}$, the linear mechanism of water uptake is altered due to the high erosion percentage of the formulations and probable change in gel structure. The swelling behavior indicated a rate at which this formulation absorbed water from dissolution media and swelled. The change in weight, characteristic of water uptake and swelling, started from the beginning and continued until $120 \mathrm{~min}$ of experiment and after that it started decreasing. The erosion measured the weight loss from matrix tablets immersed in dissolution media as a function of time. Weight loss from the tablets increased progressively with the erosion time. Polymer swelling and erosion was distinguishable among four formulations.

The evaluation of release profiles is recommended as an valuable exercise in the development and optimization of drug formulations. The release rate of aceclofenac in first two hours in acid media was so negligible (less than $10 \%$ ) for all the formulation that the result was not shown in the release curve. At this $\mathrm{pH}$, Aceclofenac exists in its acidic form which is well known to be practically insoluble in the stomach (Sheu et al., 1962; Kincl et al., 2004). When the dissolution was changed to $\mathrm{pH} 6.8$ phosphate buffer media, the drug release rate was slightly increased, 
possibly because the aceclofenac was partially converted to aceclofenac salt which is soluble and also because of swelling and erosion phenonmenon. The release of drug in SCF is very high due to the presence of enzymes and a significant differences (P-value $<<0.05$ ) was observed between different formulations formulated with varying proportions of xanthan gum. The drug release from $\mathrm{AXT}_{1}$ $(101.14 \pm 0.89 \%)$ was high, while it was low for $\mathrm{AXT}_{4}$ $(89.11 \pm 0.17 \%)$ at the end of the $12^{\text {th }}$ hour. The reason for this may be low concentration of polymer in $\mathrm{AXT}_{1}$ and high concentration in $\mathrm{AXT}_{4}$ which caused hydration of xanthan gum particles in neutral medium resulted in extensive swelling. Hence it may be suggested that, the well Separated particles comes in contact with the dissolution media and thereby swollen and coalesced. This resulted in formation of continuous viscoelastic matrix which fills the interstices, maintaining the integrity of the tablet and retarding further liquid penetration (Dhopeshwarkar et al., 1993). As a result of a high swelling, Xanthan gum matrix tablets can sustain drug release in SCF. Xanthan gum has a substantial ability to swell and form a hydrogel in neutral medium hence the initial drug release takes place in SIF (Yeole et al., 2006) where as the enteric polymers remain insoluble in the gastric $\mathrm{pH}$ and intestinal $\mathrm{pH}$ and thus controlling the release of drug within the desired range (Sinha et al., 2007) It has been reported that polymer concentration is found to influence the release characters of the drug from the dosage form (Akanksha, Raj Kumar, 2009). 3 In our study, Xanthan gums in varying proportions $(4,8,12$ and $15 \% \mathrm{w} / \mathrm{w}$ to tablet weight) release the drug in the following order. $\mathrm{AXT}_{1}>\mathrm{AXT}_{2}>\mathrm{AXT}_{3}>\mathrm{AXT}_{4}$ over a period of $8 \mathrm{hr}$ in SCF.

The second part of the formulation focused on the polymer coating of the xanthan gum tablets. The tablets were coated in a fluidized bed coating apparatus. Owing to the ability of Eudragit S-100 and Eudragit L-100, to dissolve above $\mathrm{pH} 7.0$ and to protect the drug in the upper gastrointestinal tract, they are employed in the ph sensitive coating. Hence when the enteric coating comes in contact with the colonic $\mathrm{pH}$, it dissolves, and there after it is expected that drug release would be controlled by xanthan gum. Taking into account the dissolution profiles of all the xanthan gum-aceclofenac tablets, the $\mathrm{AXT}_{1}$ was selected as optimized formulation as its dissolution profile was akin to the expected requirements of the study. Further the Eudragit coating of the optimized formulation E-AXT $\mathrm{A}_{1}$ has reduced the drug release to a great extent in the stomach, however maintain the same dissolution profile in SCF.

The drug release kinetics was evaluated by fitting various mathematical models, viz, zero-order, first-order, Higuchi, or Korsemeyer-Peppas equation. The reason why drug release rate from the tablet is reduced in the presence of increasing concentration of xanthan gum, was may due to the formation of a gel through which the drug must diffuse. The drug release kinetics of all the formulations were presented in table.3. Interestingly, release data of all the tablet formulations fitted well with zero-order release model with a coeficient of determination $\left(\mathrm{r}^{2}\right)$ greater than 0.99 . Where as matrix tablets did not show a good fit with first order model with a coefficient of determination $\left(\mathrm{r}^{2}\right)$ between $0.566-0.75$. From the coefficient of determination values (shown in Table III), it appears that the Higuchi model seems the best-fitting model, which suggests a diffusion-controlled release mechanism by pore formation. The release mechanism is also influenced by porosity and tortuosity of the matrix (Florence, Attwood, 1988). Thus gradually reducing the diffusion path length, which in turn attenuates the decrease of the release rate in the Higuchi model, making the pattern to resemble zero-order model. The drug release data were fitted to the power law or the Korsemeyer-Peppas equation as shown in Table III. In this study, xanthan gum tablets showed a good fit into the Korsemeyer-Peppas equation, exhibited a c coeficient of determination $\left(\mathrm{r}^{2}\right)$ greater than 0.98 for all the formulation. For the case of matrix tablets, $0.45<\mathrm{n}$ corresponds to a Fickian diffusion mechanism and $\mathrm{n}=0.89$ indicates a purely relaxed controlled delivery which is referred to as Case II transport. Intermediate values $0.45<\mathrm{n}<0.89$ indicate an anomalous behavior (non-Fickian kinetics corresponding to coupled diffusion / polymer relaxation). Occasionally, values of $n>0.89$ have been observed, which has been regarded as Super Case II kinetics. The calculated exponents (n) were in the range from 0.70 to 0.81 , indicating an non-Fickian diffusion mechanism. Our results clearly advocate the non-Fickian diffusion owing to the coupling of diffusion process with the mechanical response of the polymer. The value of $\mathrm{n}$ is 0.5 for Fickian transport and $>0.5$ and $<1.0$ for non-Fickian transport and 1 for zeroorder (Case-II transport). When the value of $n$ approaches 1.0 , phenomenologically one may conclude that the release is approaching zero-order. Figs. 5-6 reveal that the rate of release decreased with time and this may be due to an increase in diffusional path length for the drug which in turn may be due to slower erosion rate of the rubbery layer and faster advancement of swelling front into the glassy polymer. The release pattern swiftly deviated from $\mathrm{AXT}_{1}$ to $\mathrm{AXT}_{4}$. This may also be attributed to the synergistic increase in gel viscosity at the tablet periphery. This will decrease the rate of advancement of swelling front into the glassy matrix resulting in a slow diffusion of the drug. As the swelling front advances into the glassy polymer, the rubbery state, polymer (gel at the tablet periphery) which 
is devoid of the drug, undergoes attrition. When these two rates are equal, the diffusional path length for the drug remains constant and zero-order release will be seen. The value of $r^{2}$ was also found to be higher for the Higuchi model. Hence the release pattern also follows the Higuchi model. The solvent molecule diffuses into the polymer creates an osmotic pressure. The initial swelling at the surface then creates additional surface for the additional penetrant and thus leads to the formation of viscoelastic mass which gives its glassy state. Moreover the accumulation of solvent around the periphery of tablet creates a solvent shock which also causes the drug release. At the end of the release process, all the polymer materials are completely dissolved in case if it follows the zero order and Higuchi mechanisms. The drug release slows down with the increase in the viscosity of the gel forming polymer. The exponent ' $n$ ' decreases with the increase

The insoluble polymeric matrix of the table core of the present invention is sufficiently strong to retard the rate of release of the active ingredient or drug from the core. In addition, the tablet core provides a backbone for the outer rate controlling membrane. The polymeric matrix core prevents shrinkage and rupture of the membrane coating on exposure to gastrointestinal fluid. It also provides a tortuous path for penetrating gastrointestinal fluid, thereby keep a drug reservoir in the membrane coated polymeric matrix for a longer period of time.

From the comparative analysis of different concentrations of the polymers on the dissolution profile of the drug in the colon, we learned that the xanthan gumAceclofenac formulation E-AXT 1 appears promising for colon targeting as it inhibited drug release in upper GIT and exhibited maximum release in SCF in a sustained manner. From the over all results, it can be understood that the drug release takes place through the formation of pores and channels initially, followed by swelling of the polymer around the drug matrix that sustain the release of the drug. From the dissolution profile, it was evident that with the increase in polymer concentration, thickness of the swelling around the drug matrix increases which further slows down the release characteristics of the drug. Hence drug release could be a result of the combination of fine dependent hydration of xanthan gum and enzymatic degradation by colonic bacteria.

\section{CONCLUSION}

The present study focussed on viability of tablets of Aceclofenac prepared with xanthan gum for controlled and colon specific delivery in chronotherapy of rheumatoid arthritis. Xanthan gum and Eudragit coated tablets offer a greater degree of protection from premature drug release in the upper GI tract than xanthan gum alone. The xanthan gum is still available for enzymatic degradation, which allows greater drug release under conditions that may be expected to pertain in the colon. By changing the variables such as the xanthan gum to aceclofenac ratio, it may be possible to produce a system with a release profile, which is tailored to meet the particular requirements of any individual drug. The in vitro studies suggest that xanthan gum tablets of aceclofenac are promising for the therapy of rheumatoid arthritis. A further detailed study in human subjects will through more light on their efficacy and compliance.

\section{ACKNOWLEDGEMENT}

We are extremely thankful to Dr. Ramakrishnan, for helping us in the technical aspect of the project and also for useful scientific discussions, which produced ground breaking results. We also would like to extend our gratitude to Prof. Indhrani Ramasamy and Prof. Karthika Ramakrishnan for sharing their passion for chemistry and bio-engineering and thus helping us in the chemistry basis of polymers, which lead to better understanding of polymers and materials.

\section{REFERENCES}

AKANKSHA, T.; RAJ KUMAR, S. Natural polymer in colon targeting. Int. J. Pharm. Clin. Res., v.1, n.2, p. 43-46, 2009.

AULTON, M.E.; WELLS, J.I. Pharmaceutics. The science of dosage form design. London: Churchill Livingstone, 1988. p.247-249.

AVACHAT, A.; KOTWAL, V. Design and evaluation of matrixbased controlled release tablets of diclofenac sodium and chondroitin sulphate. AAPS PharmSciTech.,v.8, n.4, p.8896, 2007.

BI, Y.; SUNADA, H.; YONEZAWA, Y.; DANJO, K.; OTSUKA, A.; LIDA, K. Preparation and evaluation of a compressed tablet rapidly disintegrating in oral cavity. Chem. Pharm. Bull., v.44, n.11, p.2121-2127, 1996.

CARR, R.L. Evaluating flow properties of solids. Chem. Eng., v.72, n.3, p.163-168, 1965.

CHOURASIA, M.K.; JAIN, S.K. Pharmaceutical approaches to colon targeted drug delivery systems. J. Pharm. Sci., v.6, n.1, p.33-36, 2003. 
DHAWALE, S.C.; BANKAR, A.S.; PATRO, M.N. Formulation and Evaluation Porous Microspheres of 5- Fluorouracil for Colon Targeting. Int. J. Pharm. Tech. Res.. v.2, n.2, p.1112$1118,2010$.

MEDICINE ONLINE. Diclofenac Sodium Delayed-release Tablets, USP. Available at: <http://www.medicineonline. com/drugs/d/2288/Diclofenac-Sodium-Delayed-releaseTablets USP.html.>. Accessed on: 14. jun. 2010

DRUG DETAILS. EPG Mobile beta. Available at: < http://www. epgonline.org/mobile/drug-details.cfm/id/DR004273/page/ atoz/letter/a/language/LG0001/startrow_drug/1/drugName/ Aceclofenac-100-mg-Tablets>. Accessed on: 13 may 2010.

DHOPESHWARKAR, V.; O’KEEFFE, J.C.; HORTON, M. Development of an oral sustained release antibiotic matrix tablet using invitro/invivo correlations. Drug Develop. Ind. Pharm., v.20, n.11, p.1851-1867, 1994.

FLORENCE, A.T.; ATTWOOD, D. Physicochemical principles of pharmacy. 3.ed. London: Macmillan Press Ltd., 1998. H 48. p.5-85.

GANG CHENG; FENG AN; MEI-JUAN ZOU; JIN SUN; XIU-HUA HAO; YUN-XIA HE. Time- and $\mathrm{pH}$ - dependent colon-specific drug delivery for orally administered diclofenac sodium and 5- aminosalicylic acid. World J. Gastroenterol., v.10, n.12, p.1769-1774, 2004.

GOHEL, M.C.; BANSAL, G.; BHATT, N. Formulation and evaluation of orodispersible taste masked tablets of famotidine. Pharm. Biol. World, v.3, n.6, p.75-80, 2005.

MEHRGAN, H.; MORTAZAVI, S.A. The release behavior and kinetic evaluation of diltiazem HCL from various hydrophilic and plastic based matrices. Iran J. Pharm. Res., v.3, n.3, p.137-146, 2005.

HALSAS, M.; HIETALA, J.; VESKI, P.; JURJENSON, H.; MARVOLA, M. Morning versus evening dosing of ibuprofen using conventional and time controlled release formulations. Int. J. Pharm., v.189, n.2, p.179-185, 1999.

HALSAS, M.; PENTTINEN, T.; VESKI, P.; JURJENSON, H.; MARVOLA, M. Time controlled release pseudoephedrine tablets: bioavailability and in vitro/in vivo correlations. Pharmazie, v.56, n.114, p.718-723, 2001.
HAUSNER, H.H. Friction conditions in a mass of metal powder. Int. J. Metall., v.3, n.9, p.7-13, 1967.

KAY, A.E.; ALLDRED, A. Rheumatoid arthritis and osteoarthritis. In: WALKER, R., EDWARDS, C. (Eds.). Clinical pharmacy and therapeutics. 3.ed. London: Churchill Livingstone, 2003. p.791-807.

KINCL, M.; VREVER, F.; VEBER, M. Characterization of factors affecting the release of low-solubility drug from prolonged release tablets. Anal. Chim. Acta., v.502, n.7, p.107-113, 2004.

KINGET, R.; KALALA, W.; VERVOORT, L.; VAN DEN MOOTER, G. Co- lonic drug targeting. J. Drug Target., v.6, n.2, p.129-149, 1998.

LACHMAN, L.; LIEBERMAN, H.A.; KANIG, J.L. The theory and practice of industrial pharmacy. 3.ed. Mumbai: Varghese Publishing House, 1987. p.182-184, 296-303, 311-312.

LEHMANN, K.O.R.; DREHER, K.D. Methacrylategalactomannan coating for colon-specific drug delivery. Proc. Int. Symp. Control. Rel. Bioact. Mater., v.18, n.194, p.331-332, 1991.

LIU, L.; FISHMAN, M.L.; KOST, J.; HICK, K.B. Chondroitin sulphate based systems for colon - specific drug delivery via oral route. Biomaterials, v.246, n.3, p.3333-3343, 2003.

MANEK, N. J.; LANE, N.E. Osteoarthritis: Current Concepts in Diagnosis and Management. Am. Fam. Physician, v.61, n.12, p.1795-804, 2000.

MOMIN, M.; PUNDARIKAKSHUDU, K. In vitro studies on guar gum based formulations for the colon targeted delivery of sennosides. J. Pharm. Pharmaceut., v.7, n.3, p.325-331, 2004.

MOSKOWITZ, R.W. The role of anti-inflammatory drugs in the treatment of osteoarthritis: a United States viewpoint. Clin. Exp. Rheumatol., v.19, n.6, p.S3-8, 2001.

MUNDARGI, R.C.; PATIL, S.A.; AGNIHOTRI, S.A.; AMINABHAVI, T.M. Development of polysaccharidebased colon targeted drug delivery systems for the treatment of amoebiasis. Drug Dev. Ind. Pharm., v.33, n.3, p.255-264, 2007. 
MUTALIK,S.; MANOJ, K.; SREENIVASA REDDY, M.; KUSHTAGI, P.; NAYAK USHA, A.; ANJU, P.; KUMAR RANJITH, A.; UDUPA, N. Chitosan and enteric polymer based once daily sustained release tablets of Aceclofenac: in vitro and in vivo studies. AAPS PharmSciTech., v.9, n.2, p.651-659, 2007.

NSAIDs for Rheumatoid Arthritis. Rheumatoid arthritis guide. Available at: <http://www.webmd.com/rheumatoidarthritis/guide/nsaids-rheumatoid-arthritis $>$. Accessed on: 12. april 2009.

NTAWUKULILYAYO, J.D.; VERVAET, C.; REMON, J.P.; GÖRTZ, J.P.; BERLO, J.A. In vitro and in vivo evaluation of a xanthan gum-n-octenylsuccinate starch matrix tablet containing ibuprofen as a model containing ibuprofen as a model drug. Int. J. Pharm., v.139, n.2, p.79-85, 1996.

PAHARIA, A.; YADAV, A.K.; RAI, G.; JAIN, S.K.; PANCHOLI, S.S.; AGRAWAL, G.P. Eudragit-coated chondroitin sulphate microspheres of 5-fluorouracil for colon targeting. AAPS PharmSciTech., v.8, n.1, p.135-146, 2007.

PARFITT, K. Analgesics, anti-inflammatory and antipyretics. In: REYNOLDS, J.E.F. (Ed.). MARTINDALE: The complete drug reference. 32.ed. Massachusetts, London: Pharmaceutical press, 1999. p.1-12.

RAVI KUMAR; PATIL, M.B.; PATIL, S.R.; MAHESH S.P. Polysaccharides based colon specific drug delivery: A Review. Int. J. Pharm. Tech. Res., v.1, n.2, p.334-346, 2009.

RAJA SEKHARAN, T.; PALANICHAMY, S.; SHANMUGANATHAN, S.; KARTHIKEYAN, A.; SENTHILKUMAR, S.R.; THIRUPATHI, T. Formulation and Evaluation of Theophylline Controlled Release Matrix Tablets using Xanthan gum. Der Pharm. Let., v.1, n.2, p.93-101, 2009.

SALYERS, A.A.; VERCELLOTTI, J.R.; WEST, S.H.E.; WILKINS, T.D. Fermentation of mucin and plant polysaccharides by strains of bacteroides from the human colon. Appl. Environ. Microbiol., v.33, n.2, p.319-322, 1977.

SARASIJA, S.; HOTA, A. Colon-specific drug delivery systems. Ind. J. Pharm. Sci., v.62, n.1, p.1-8, 2000.

SHEU, M.; CHOU, H.; KAO, C.; LIU, C.; SOKOLOSKI, T.D. Dissolution of diclofenac sodium from matrix tablets. Int. J. Pharm., v.85, n.1-3, p.57-63, 1992.
SINHA, V.R.; MITTAL, B.R.; BHUTANI, K.K.; RACHNA KUMARI. Colonic drug delivery of 5 fluorouracil: an in vitro evaluation. Int. J. Pharm., v.269, n.1, p.101-108, 2004.

SINHA, V.R.; ASMITA SINGH.; SANJAY SINGH.; BHINGE, J.R. Compression coated systems for colonic delivery of 5-fluorouracil. J. Pharm. Pharmacol., v.59, n.3,p.359-365, 2007.

SWARBRICK, J. Encyclopedia of pharmaceutical technology. 3.ed. New York: Informa healthcare, 2007. v.6, p.26142629.

TALUKDAR, M.M.; KINGE, R. Swelling and drug release behaviour of xanthan gum matrix tablets. Int. J. Pharm., v.120, n.1, p.63-72, 1995.

TRAIN, D. Some aspects of the property angle of repose of powders. J. Pharm. Pharmacol., v.10, n.11, p.127-135, 1958.

UNITED STATES PHARMACOPOEIA. 24-NF-19. Rockwille: US Pharmacopeial Convention, 1999. p.587-598.

UNITED STATES PHARMACOPOEIA. XXVII. Rockville: US Pharmacopeial Convention, 2004. p.2300-2304.

UNITED STATES PHARMACOPOEIA, $19^{\text {th }}$ ed., 2008. Available at: $<$ http://www.usp.org $>$. Accessed on: $9^{\text {th }}$ Sep 2009.

VAIDYA, A.; JAIN, A.; KHARE, P.; AGRAWAL, R.K.; JAIN, S.K.; Metronidazole loaded pectin microspheres for colon targeting. J. Pharm. Sci., v.98, n.11, p.4229-4236, 2009.

YANG, L.; CHU, J.S.; FIX, J.A. Colon-specific drug delivery: new approaches and in vitro/in vivo evaluation. Int. J. Pharm., v.235, n.1, p.1-15, 2002.

YEOLE, P.G.; GALGATTE, U.C.; BABLA, I.B.; NAKHAT.P.D. Design and evaluation of Xanthan gum-based sustained release Matrix tablets of Diclofenac sodium. Ind. J. Pharm. Sci., v.68, n.2, p.185-189, 2006.

WATTS, P.J.; ILLUM, L. Colonic drug delivery. Drug Dev. Ind. Pharm., v.23, n.9, p.893-913, 1997.

Received for publication on $24^{\text {th }}$ May 2010. Accepted for publication on $04^{\text {th }}$ December 2010 . 